\title{
Lytic JC Virus Infection in the Kidneys of AIDS Subjects
}

Renzo Boldorini, M.D., Elisabetta Omodeo-Zorini, M.Sc., Manuela Nebuloni, M.D., Elisabetta Benigni, B.Sc., Luca Vago, M.D., Angelita Ferri, M.D., Guido Monga, M.D.

Dipartimento di Scienze Mediche, Facoltà di Medicina e Chirurgia, Università "Amedeo Avogadro" del Piemonte Orientale (RB, EO-Z, EB, GM), Novara, Italy; and Servizio di Anatomia Patologica Ospedale di Vimercate (Milano; MN) and V Cattedra di Anatomia Patologica, Facoltà di Medicina e Chirurgia, Università di Milano (LV, AF), Milan, Italy

Our objective was to investigate the role of the human polyomavirus JC virus as a possible cause of renal damage in AIDS subjects. Histology, immunohistochemistry, and molecular biology were used to evaluate the frequency of viral infection, genotypes, viral status, and the presence of rearrangements or point mutations in specific genomic regions of strains isolated from renal tissue. Formalin-fixed, paraffin-embedded sections of postmortem renal specimens obtained from 111 unselected AIDS patients were stained for routine histology and with anti-SV40 antibody. The immunohistochemically positive specimens were further investigated by means of nested polymerase chain reaction for different polyomavirus genomic regions (large $T$, transcriptional control region, and viral protein 1). Furthermore, the sequences of transcriptional control region and viral protein 1 were also analyzed. Immunohistochemistry was positive in seven cases (6.3\%), four of which showed morphological evidence of viral replication (intranuclear inclusion bodies and/or intratubular cellular casts): in all seven cases, only epithelial tubular cells (with and without inclusion bodies) and cellular casts were stained. The JC virus genome was identified by polymerase chain reaction in five of the seven immunohistochemically positive cases; transcriptional control region and viral protein 1 were amplified in, respectively, three and four cases. Transcriptional control region sequence analysis revealed major rearrangements in all three cases, with duplications of all the transcriptional factor-binding sites, whereas no point mutations were found in the viral protein

Copyright () 2003 by The United States and Canadian Academy of Pathology, Inc.

VOL. 16, NO. 1, P. 35, 2003 Printed in the U.S.A.

Date of acceptance: August 27, 2002.

Partially supported by a grant from FUJISAWA, s.r.l., Milan, Italy.

Address reprint requests to: Renzo Boldorini, M.D., Dipartimento di Scienze

Mediche, Facoltà di Medicina e Chirurgia, Università del Piemonte Orientale,

Via Solaroli 17, 28100 Novara, Italy; e-mail: renzo.boldorini@med.unipmn.it; fax: 39-0321-3733485.

DOI: 10.1097/01.MP.0000044622.04245.A9
1 region, which was characterized as Type $1 \mathrm{~A}$ in all cases. For the first time in AIDS subjects, this study shows that although rarely, JC virus can replicate in renal tissue. Molecular biology revealed major rearrangements in the transcriptional control region that, together with other unknown factors, could justify the increased pathogenicity of this human polyomavirus.

KEY WORDS: AIDS, Immunohistochemistry, JC virus, Kidney, Molecular biology, Polyomavirus.

Mod Pathol 2003;16(1):35-42

The JC virus is a member of the polyomavirus family, known as the etiological agent of progressive multifocal leukoencephalopathy, a demyelinating disease of the central nervous system caused by lytic infection of oligodendroglial cells (1). Progressive multifocal leukoencephalopathy mainly affects AIDS patients but has also been reported in subjects with Hodgkin's disease, sarcoidosis, tuberculosis, and, rarely, in transplanted patients in whom JC virus may reactivate because of impaired cellmediated immunity (2-5). The central nervous system and the kidney are considered reservoirs of JC virus infection, in which the virus persists in a latent state after primary infection (6). Unlike the other human member of the polyomavirus family, the $\mathrm{BK}$ virus, which is known to be responsible for tubulointerstitial nephritis (BK virus-nephropathy), after its reactivation in transplanted and AIDS patients $(7,8)$, the JC virus for a long time was not considered as a possible causative agent of renal damage.

Although genomic sequences of both JC virus and BK virus DNA have been amplified by means of polymerase chain reaction (PCR) from renal biopsies of transplanted and AIDS patients, combined immunohistochemical and molecular biology studies indicated that the renal damage was always due to the replication of BK virus, whereas JC virus is present as a latent co-infecting agent $(7,10)$. These 
findings seem to indicate that the two polyomaviruses have a narrow spectrum of organs in which they can cause diseases. Randhawa et al. (11) have recently reported for the first time in a setting of tubulointerstitial nephropathy an immunohistochemical demonstration of JC virus replication in the epithelial tubular cells of a kidney transplant patient, thus showing that the kidney can also be a target for JC virus-induced disease. From the molecular point of view, their results were confirmed by the sequence analysis of JC virus protein coding regions (VP 1-3), but no data were reported concerning the nucleotide sequence of the transcriptional control region (TCR), a non-coding and hypervariable genomic region that controls viral transcription, replication, and cellular host range (12), whose analysis is mandatory to evaluate modifications in cell tropism and infectivity.

We investigated the possible role of JC virus in inducing renal damage by means of histology and immunohistochemistry examinations of postmortem renal specimens taken from unselected AIDS patients. Furthermore, molecular biology analyses of the viral strains isolated from renal tissue and sequence analyses of the JC virus TCR and VP1 regions were also performed to evaluate viral genotypes and modifications in the viral genome.

\section{MATERIAL AND METHODS}

We retrospectively examined postmortem renal samples obtained from 111 unselected AIDS patients (80 male and 31 females with a mean age of 45 y: range 25-64) between 24 and 96 hours after death at "L. Sacco" Hospital, Milan, from 1992 to 1998. The patients included 69 intravenous drug users, 30 homosexuals and 12 patients with at-risk sexual relationships.

\section{Histology and Immunohistochemistry}

The renal specimens were fixed in formalin for 24 hours, embedded in paraffin and routinely pro- cessed. Step sections of $4 \mu \mathrm{m}$ thick were stained with hematoxylin and eosin (H\&E) and periodic acid-Schiff (PAS) and processed using a polyclonal antibody against simian virus SV40 (Lee Biomolecular Research Labs, San Diego, CA; dilution, 1:20.000), which cross-reacts with human BK virus and JC virus (13). The reactions were detected by means of the streptavidin-biotin method and revealed using diaminobenzidine as the chromogen (14).

\section{Molecular Biology}

The immunohistochemically positive specimens were further investigated by means of molecular biology. DNA was extracted from paraffinembedded renal samples by means of digestion with proteinase $\mathrm{K}$, as previously reported (15). To avoid false-negative results, nested PCR (nPCR) of the human androgen-receptor gene was performed in all cases as a positive control of DNA extraction.

To identify the presence of polyomavirus sequences, the DNA was submitted to nPCR for the large $\mathrm{T}$ antigen (LT) region, which is common to both the human polyomaviruses JC virus and $\mathrm{BK}$ virus. $\mathrm{JCl}_{\mathrm{D}}$ and $\mathrm{JC} 2{ }_{\mathrm{D}}$ primers were used for the outer n-PCR, and PEP1 and PEP2, for the inner PCR (16). The amplified products were characterized by means of restriction fragment length polymorphism analysis using BamHI restriction endonuclease, which cuts genomic fragments of JC virus but not BK virus. All samples were also tested with two sets of primers similar to those used by Bergsagel et al. (17), but modified to make them specific for the LT region of SV40. (All of the sequence primers are shown in Table 1)

The second step was to search for specific fragments of the TCR regions of the JC virus to identify specific viral variants. The outer n-PCR for the TCR region was performed using the primers BKTT1 and BKTT2, which are common to both the JC virus and the BK virus (18); a specific inner PCR for JC virus was performed using JRI1 and JRE2 $(19,20)$.

TABLE 1. Primers Used for Amplification of BK Virus, JC Virus and SV40 LT, and JC Virus TCR and VP1 Regions

\begin{tabular}{|c|c|c|c|}
\hline Region & & Name & Sequence $\left(5^{\prime}-3^{\prime}\right)$ \\
\hline \multirow[t]{4}{*}{ LT (JCV and BKV) } & Outer & $\mathrm{JCl}_{\mathrm{D}}$ & -AAY ACA gCT TgA CTR AgR- \\
\hline & & $\mathrm{JC} 2_{\mathrm{D}}$ & -gCT TCA SAC ART ggT TTg gS- \\
\hline & Inner & PEP1 & -AgT CTT TAg ggT CTT CTA CC- \\
\hline & & PEP2 & -ggT gCC AAC CTA Tgg AAC Ag- \\
\hline \multirow[t]{4}{*}{ LT (SV40) } & Outer & PYV.for & -TAg ATT CCA ACC TAT ggA ACT gA- \\
\hline & & PYV.rev & -ggA Aag TCC TTg ggg TCT TCT ACC- \\
\hline & Inner & SV.for3 & -TgA ggC TAC TgC TgA CTC TCA ACA- \\
\hline & & SV.rev & -gCA TgA CTC AAA AAA CTT AgC AAT TCT g- \\
\hline \multirow[t]{4}{*}{ TCR (JCV) } & Outer & BKTT1 & -AAg gTC CAT gAg CTC CAT ggA TTC TTC C- \\
\hline & & BКTT2 & -CTA ggT CCC CCA AAA gTg CTA gAg CAg C- \\
\hline & Inner & JRI1 & -CTC CAC gCC CTT ACT ACT TCT- \\
\hline & & JRE2 & -TAC gTg ACA gCT ggC gAA gAA- \\
\hline \multirow[t]{2}{*}{ VP1 (JCV) } & & JLP15 & -ACA gTg Tgg CCA gAA TTC CAC TAC C- \\
\hline & & JLP16 & -TAA AgC CTC CCC CCC AAC AgA AA- \\
\hline
\end{tabular}

LT, large T antigen region; TCR, transcriptional control region; VP1, viral capsid protein region 1. 
Finally, a 215-bp sequence from the VP1 coding region was amplified by means of single-step PCR using the primer pair JLP 15 and JLP 16. These PCR products include 16 known typing sites, which distinguish JC virus types 1-7.

DNA extracted from (1) autopsy brain tissue of an AIDS subject with progressive multifocal leukoencephalopathy, (2) renal tissue from a patient with BK virus nephropathy, and (3) SVG cell line were used as positive controls in PCR procedures for JC virus, BK virus, and SV40, respectively. Distilled water was also tested as negative control during PCR procedures.

The cycle-sequencing reaction of the TCR and VP1 regions was performed according to the manufacturer's instructions using an ABI PRISM BigDye Terminator Cycle Sequencing Ready Kit (PE Biosystems, Foster City, CA). Fluorescence-based DNA sequence analyses of both strands of PCR products were obtained with $\mathrm{ABI} 373$ DNA sequencer (PE Biosystems).

\section{RESULTS}

\section{Histology and Immunohistochemistry}

Immunohistochemistry showed that renal tissue specimens were anti-SV40 antibody positive in 7 (6.3\%) of 111 patients. Progressive multifocal leukoencephalopathy was found in two of the latter, as shown by the presence of anti-SV40 positive cells in brain tissue. The main light microscopy findings are summarized in Table 2.

Two types of intranuclear inclusion bodies were identified: an amorphous, basophilic ground-glass variant and a vesicular variant with enlarged nuclei containing clumped chromatin, which were respectively classified as Types 1 and 4 according to Nickeleit et al. (21). They are considered to be the morphological expression of viral replication in the nuclei of infected cells. Inclusion bodies were abundant but focally distributed in the renal parenchyma in Cases 1 and 3, in which many convolute tubules appeared to be entirely involved in crosssection. Conversely, only rare ground-glass inclusions were detected in the epithelial cells of one Henle's loop in Case 4. Despite a careful search, no inclusion bodies were found in Cases 2, 5, 6, or 7 .

Another important morphological finding was the presence of intratubular casts consisting of necrotic cells detached from the basal lamina. Casts were abundant in Cases 1 and 3, with the denudation of a large portion of the tubular basal membranes and frequent images of regenerative changes (Fig. 1A; such as nuclear hypertrophy and mitosis); they were rare in Case 6.

Inflammatory infiltration was only found in Case 4 , in which cortical foci of polymorphonuclear cells were detected in the interstitium and tubules in a setting of bacterial sepsis also involving the renal parenchyma.

Anti-SV40 antibody stained the nuclei of epithelial tubular cells in all cases, whereas glomerular cells, the parietal epithelium of Bowman's capsule, and endothelial and interstitial cells were always negative. Positively stained nuclei were mainly found in convolute tubules and less frequently in medullary tubules and Henle's loops (Fig 1b); approximately $40-50 \%$ of the cells bearing intranuclear viral inclusions in Cases 1 and 3 and most of the tubular casts stained positively, but, interestingly, positive staining was also found in the nuclei of the epithelial tubular cells in all seven cases without any morphological evidence of viral infection. The intensity of the staining was strong in the nuclei bearing viral inclusions, but light in the nuclei of the cells without inclusion bodies.

The intrarenal distribution of immunostaining was always focal or multifocal, and single positively

TABLE 2. Light Microscopy Findings in Cases Positively Stained by Anti-SV40 Antibody

\begin{tabular}{|c|c|c|c|c|c|}
\hline $\begin{array}{c}\text { Case } \\
\text { Number }\end{array}$ & Age (y)/Sex & Viral Inclusions & $\begin{array}{l}\text { Distribution of IHC- } \\
\text { Positive Cells }\end{array}$ & $\begin{array}{l}\text { Tubular } \\
\text { Casts }\end{array}$ & $\begin{array}{l}\text { Other Extrarenal } \\
\text { Pathological Findings }\end{array}$ \\
\hline 1 & $36 / \mathrm{M}$ & $\begin{array}{l}\text { Abundant } \\
\text { Types } 1 \text { and } 4\end{array}$ & $\begin{array}{l}\text { Multifocal, cortical, } \\
\text { and medullary } \\
\text { tubules }\end{array}$ & Abundant & $\begin{array}{l}\text { CMV encephalitis, } \\
\text { bacterial pneumonia }\end{array}$ \\
\hline 2 & $43 / \mathrm{M}$ & Absent & $\begin{array}{l}\text { Focal, medullary } \\
\text { tubules }\end{array}$ & Absent & $\begin{array}{l}\text { Cerebral NHL, lung and } \\
\text { skin KS }\end{array}$ \\
\hline 3 & $32 / \mathrm{M}$ & $\begin{array}{l}\text { Abundant } \\
\text { Types } 1 \text { and } 4\end{array}$ & $\begin{array}{l}\text { Multifocal, cortical } \\
\text { tubules }\end{array}$ & Abundant & $\begin{array}{l}\text { Disseminated NHL, } \\
\text { bacterial pneumonia }\end{array}$ \\
\hline 4 & $31 / \mathrm{F}$ & $\begin{array}{l}\text { Rare } \\
\text { Type } 1\end{array}$ & $\begin{array}{l}\text { Multifocal, cortical } \\
\text { tubules }\end{array}$ & Absent & $\begin{array}{l}\text { Bacterial sepsis with } \\
\text { spleen, liver, and renal } \\
\text { abscesses }\end{array}$ \\
\hline 5 & $28 / \mathrm{M}$ & Absent & $\begin{array}{l}\text { Multifocal, } \\
\text { medullary tubules }\end{array}$ & Absent & $\begin{array}{l}\text { Cerebral toxoplasmosis, } \\
\text { interstitial pneumonia }\end{array}$ \\
\hline 6 & $30 / \mathrm{M}$ & Absent & $\begin{array}{l}\text { Focal, cortical } \\
\text { tubules }\end{array}$ & Rare & PML, adrenal gland CMV \\
\hline 7 & $32 / \mathrm{M}$ & Absent & $\begin{array}{l}\text { Focal, medullary } \\
\text { tubules }\end{array}$ & Absent & PML \\
\hline
\end{tabular}

NHL, non-Hodgkin lymphoma; KS, Kaposi’s sarcoma; PML, Progressive multifocal leukoencephalopathy; CMV, Cytomegalovirus. 


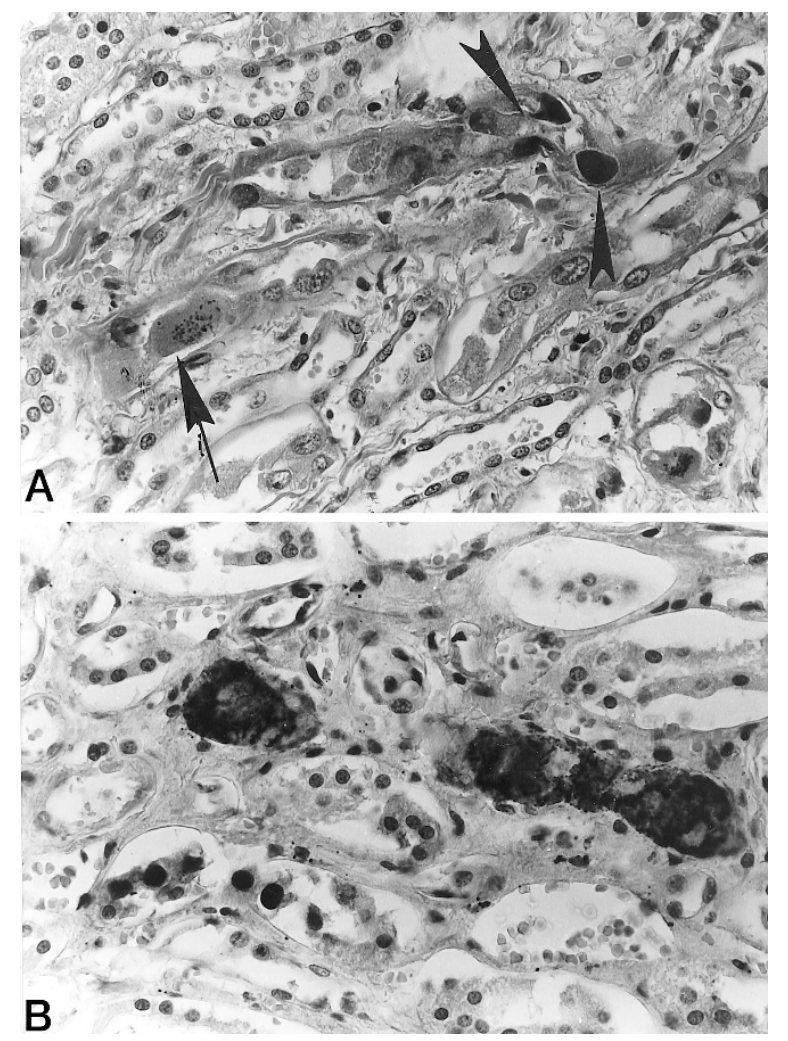

FIGURE 1. Histologic and immunohistochemical findings of renal JC virus infection. A, intranuclear viral inclusions (arrowheads) and regenerative changes of epithelial tubular cells (arrow), sometimes detached from basal lamina in a JC virus-infected renal specimen. Hematoxylin-eosin staining; original magnification, $400 \times$. B, immunohistochemical staining of viral-infected nuclei and tubular casts with anti-SV 40 antiserum. Immunoperoxidase, hematoxylin counterstaining; original magnification, $400 \times$.

stained tubules were surrounded by a large number of unstained tubules.

\section{Molecular Biology}

As shown in Table 3, polyomavirus genome was successfully detected by means of nPCR for the LT region in five of the seven cases positive by immunohistochemistry (71\%); restriction fragment length polymorphism analysis revealed only JC virus genome, whereas BK virus and SV40 were never identified.

TABLE 3. Molecular Characterization and Typing of JC Virus

\begin{tabular}{cccc}
\hline $\begin{array}{c}\text { Case } \\
\text { Number }\end{array}$ & $\begin{array}{c}\text { Genotyping } \\
\text { (LT region) }\end{array}$ & TCR & VP1 \\
\hline 1 & JCV & W5-like & $1 \mathrm{~A}$ \\
2 & JCV & W5-like & $1 \mathrm{~A}$ \\
3 & JCV & Rearranged & $1 \mathrm{~A}$ \\
4 & JCV & Not amplified & $1 \mathrm{~A}$ \\
6 & JCV & Not amplified & Not amplified \\
\hline
\end{tabular}

LT, large T antigen region; TCR, transcriptional control region; VP1, viral capsid protein region 1.
The JC virus TCR region was successfully amplified in three cases $(1,2$, and 3), and VP1, in four cases (Samples 1-4).

Despite several efforts, attempts to amplify both the JC virus TCR and VP1 regions in Sample 6 and the TCR region in Sample 4 were unsuccessful.

To identify specific viral mutations and genomic rearrangements, the sequences of the positive PCR products of the TCR and VP1 regions were analyzed. In accordance with the published data (22, 23), the sequences obtained from the TCR of Cases 1,2 , and 3 were divided into six distinct sequence sections (from A to F) and compared with the archetype, Mad1, and genomic sequences reported in the literature $(22,24)$. The TCR sequences of Cases 1 and 2 were classified as Type II derived, related to W5, whereas Case 3 showed a structure that, to the best of our knowledge, has never been reported.

As shown in Figure 2, both Samples 1 and 2 had an eight-nucleotide insertion at the end of the first C-sequence section (5'-TGA CAG CC-3') and had a four-nucleotide insertion in the second (5'-AGCC$3 ')$, deleted in W5 variant but present in the C-section of archetype sequence; however, these changes did not modify the presence or position of the transcriptional factor-binding sites in W5. The TCR of Sample 3 showed a partial duplication of the $\mathrm{A}$ and $\mathrm{D}$ regions and a duplication of all of the sequences in the $\mathrm{B}$ and $\mathrm{C}$ sections (Fig. 2). These rearrangements cause a duplication of all of the transcriptional factor-binding sites in the partially or completely duplicated regions, such as the pentanucleotide, Sp1, NF-1, GF1, and AP1 sites $(12,25)$.

Analyses of the 12 known typing sites in the VP1 region identified all of the samples as JC virus Type 1A (26). No point mutations were found in the sequence analyses of Samples 1-4.

\section{Clinical Findings}

Because this is a retrospective study, performed on autopsy material, reliable clinicopathological correlation was difficult to be assessed. Only serum creatinine levels of the last control before death were considered, being normal in six cases (27-71 $\mu \mathrm{mol} / \mathrm{L})$ and greatly increased in Case 5 (415 $\mu \mathrm{mol} / \mathrm{L})$.

\section{DISCUSSION}

Over the last few years, polyomavirus nephropathy has been increasingly reported in kidney transplant recipients $(7,10,21,27)$ and, rarely, in patients with AIDS $(8,9)$. The disease is caused by lytic polyomavirus infection of tubular epithelial cells, which reactivates under immunosuppressive conditions (28). Intranuclear viral inclusions, necrotic renal tubules and collecting ducts, and varying de- 

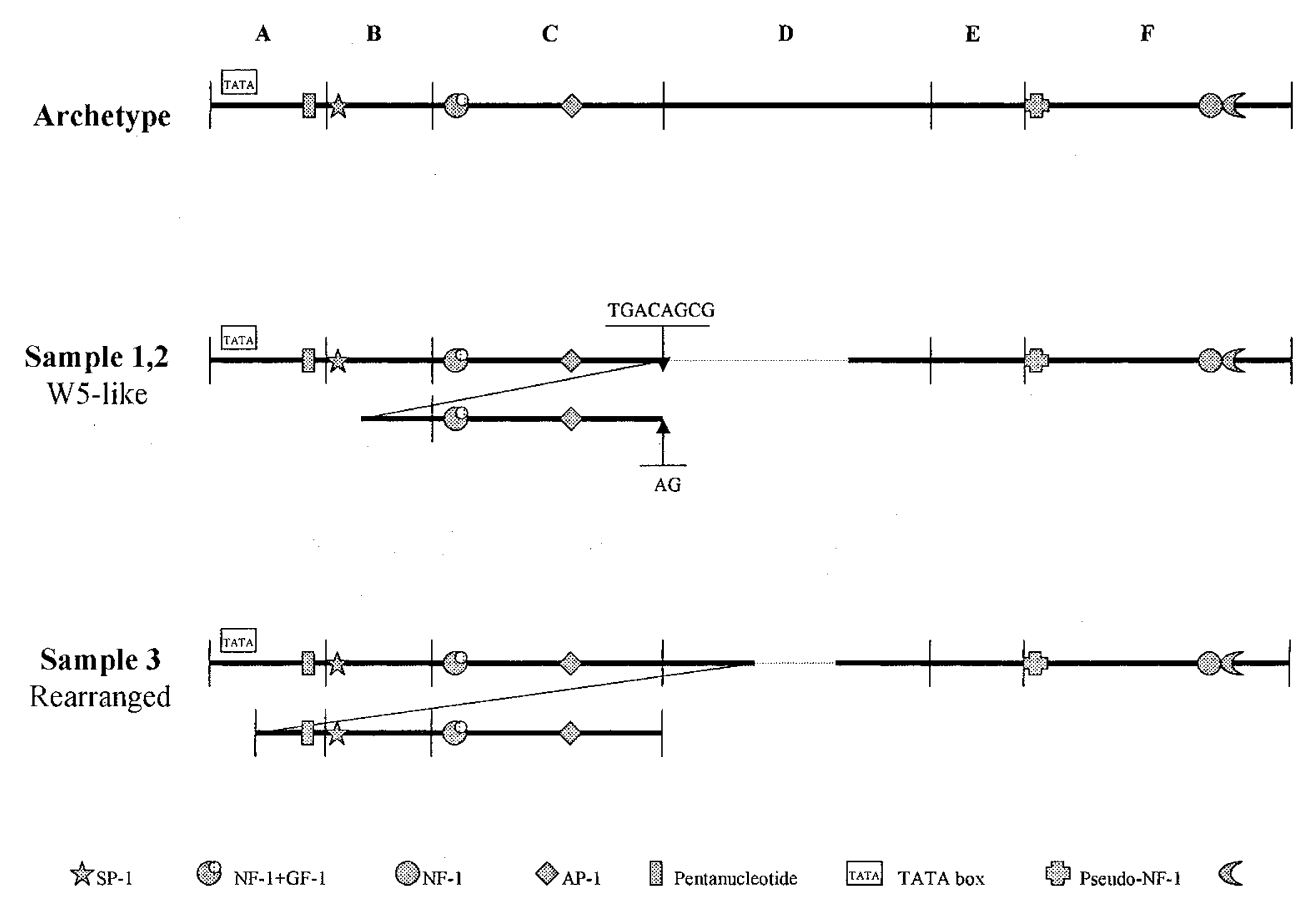

FIGURE 2. Diagrammatic representation of the rearranged JC virus-TCR sequences detected in Kidney Samples 1-3, compared with the archetype.

grees of interstitial inflammation are the main morphological findings in polyomavirus nephropathy (21). On the basis of the results of immunohistochemistry, in situ hybridization, and PCR studies, a number of authors have considered BK virus to be the only etiological agent of polyomavirus nephropathy $(7-10,21,27)$. Although JC virus genome has frequently been detected in renal tissue by means of PCR, sometimes associated with BK virus infection $(7,8,10,29-31)$, it was in a latent, nonreplicative phase and considered to be unable to produce pathological effects.

Lytic JC virus renal infection has been reported in the literature in only three patients: one had a renal carcinoma (32) and two were immunocompromised, one being affected by progressive multifocal leukoencephalopathy (33) and the other being the recipient of a kidney transplant (11). To the best of our knowledge, there are no published data concerning similar findings in AIDS patients.

We found morphological evidence of lytic polyomavirus infection in four cases, in which intranuclear viral inclusions and/or intratubular cellular casts clearly indicated active viral replication and cell damage. In all of these cases, nPCR of the LT region, followed by restriction fragment length polymorphism analysis, revealed the presence of JC virus, whereas BK virus sequences were never found. Like Aoki et al. (32) and Dorries and ter Meulen (33), we did not find any inflammatory infiltration around the renal tubules containing JC virus-positive cells or casts. Randhawa et al. (11) reported slight interstitial inflammatory infiltration in close proximity to inclusion-bearing cells stained with anti-JC virus VP1 antiserum, but their case was co-infected with BK virus, which may have been the cause of the inflammatory infiltration. However, the absence of inflammatory infiltration in our cases may also be explained by the presence of severe immunodeficiency (34) or be related to the inadequacy of the cell immune response against JC virus because of a particular virus-host interaction in renal tissue, as suggested by Agostini et al. (35).

Only about half of the nuclei of the tubular cells with viral inclusion bodies and tubular casts were positive by immunohistochemistry, and interestingly, in all seven cases, anti-SV40 antiserum also positively stained a few nuclei of epithelial tubular cells without any morphological evidence of viral infection. This antiserum, which cross-reacts with both JC virus and BK virus (13), recognizes capsid proteins VP1-3 produced after the virus replication, when viral particles are completely assembled (28). Therefore, it seems possible that cells without viral inclusion bodies were stained during the early phase of infection, when only few viral particles were present in the infected cells, but before morphologic evidence of infection.

In our cases, the immunohistochemically positive cells with morphological evidence of viral infection were randomly distributed in the renal parenchyma and focally involved renal tubules. These findings are similar to those reported by Aoki et al. (32) and Dorries and ter Meulen (33). in surgical samples, but different from those of Randhawa et al. (11), who reported the selective infection of re- 
nal cortical parenchyma by JC virus in a single kidney transplanted patient. However, because they examined a renal biopsy, the sparing of renal medullary tubules may have been more related to different sampling than to a true difference in viral tropism between AIDS and transplanted patients. On the other hand, Nickeleit et al. (21) reported a strict prevalence of renal medullary infection due to $\mathrm{BK}$ virus in their renal transplanted patients, and therefore a different cell tropism between JC virus and $\mathrm{BK}$ virus could be hypothesized.

The LT region of JC virus was amplified by means of nPCR in five of the seven cases positive by immunohistochemistry; in the other two cases, molecular analysis did not confirm the presence of viral genome. Because immunohistochemistry stained only rare cells without any morphological evidence of viral infection in these two cases, a false-positive result cannot be excluded; however it is also possible that viral DNA was no longer present in the sections used for molecular analysis, which were near to but obviously not the same as those used for histology and immunohistochemistry.

The JC virus TCR was amplified in three cases, but multiple attempts to amplify it in the other four cases were unsuccessful. This low sensitivity could be due to the small amount of viral DNA extracted from paraffin-embedded sections (36) or to the presence of multiple sequence rearrangements and mutations along the annealing primer sequences that inhibited the amplification of TCR sequences. Another explanation is that this region has a high average gC content that limits its amplification (24).

All of the amplified cases showed Type II-derived TCR sequences: Cases 1 and 2 were similar to the W5 type (37), with two insertions (eight nucleotides in the first C-sequence section and four in the second) that are present also in the archetype, but unusual major rearrangements were detected in the third specimen (partial duplication of the A and D and complete duplication of the $B$ and $C$ sequence sections). The frequency and type of rearrangements in the JC virus TCR are related to various factors, such as the type of infected cells, host immune status, and the concomitant presence of progressive multifocal leukoencephalopathy $(31,35$, 38). Major rearrangements have been reported in the brain and cerebrospinal fluid of patients with progressive multifocal leukoencephalopathy, in whom partial or entire deletions or duplications of all of the single sections from $\mathrm{A}$ to $\mathrm{F}$ have been frequently described $(22,24,37)$. Only minor changes occur in the kidney and urine of both immunocompromised and healthy subjects, in whom the length of the rearranged elements rarely exceeds $10-15$ bp $(31,35)$. However, Vaz et al. (24) and Newman and Frisque (39) have also reported duplications and insertions involving the B-E se- quence sections of JC virus in kidney and urine specimens from progressive multifocal leukoencephalopathy patients with AIDS (24), or patients with progressive multifocal leukoencephalopathy and severe immunodeficiency syndromes (39). Histological examinations of brain specimens taken from our cases did not reveal progressive multifocal leukoencephalopathy, and so the severe immune deficit may have played a more important role in inducing the major rearrangements in the JC virus TCR.

TCR is a noncoding genomic region of JC virus that is located between the early and late proteincoding regions containing promoter/enhancer sequences $(12,24)$. Although the genomic sequence of the TCR is characterized by complex hypervariability, two general types have been identified, both derived from archetype sequence (40): Type I, which includes the prototypical Madl, is characterized by the presence of a 98-bp tandem repeat, each containing a TATA box, whereas Type II contains a TATA box proximal to the early mRNA initiation site that it is not included in the repeat elements. The efficiency of JC virus transcription and replication relies on the presence of the transcription factor-binding sites, such as NF-1, Sp-1, and AP-1, that are interspersed in the TCR sequence sections $(25,41)$. Experimental models have indicated that the deletion of one or more of these sites reduces replication efficiency, whereas the duplication of any single grouping of Sections A-E could enhance the level of viral activity and contribute to the pathogenic potential of the virus (12, 42).

In our cases, the pathological significance of the TCR rearrangements was unclear. Case 3 showed unusual rearrangements, with the duplication of a large part of the transcription factor-binding sites present in the TCR and, as expected, the intranuclear viral inclusions and intratubular cellular casts showed active JC virus replication. On the other hand, although duplications of transcription factorbinding sites were also found in Cases 1 and 2, the histological findings indicated active replication only in Case 1; in Case 2, there were very few epithelial cells positive by immunohistochemistry and no morphological evidence of viral replication. Although no definite conclusions can be drawn from the examination of only three cases, these findings seem to indicate that JC virus TCR rearrangements need other unknown factors to induce active viral replication, at least in the kidney of AIDS patients.

The JC virus VP1 coding region was amplified in four cases, and on the basis of the sequence analysis of specific polymorphic sites, all were classified as Type 1A, the most frequently found strain in Europe (26). The sequence analyses did not reveal 
any nucleotide changes in our cases, but Baksh et al (43) observed point mutations in the VP1 region in $3 / 6$ cases of JC virus renal infection in transplanted patients that did not modify amino acid sequences. On the contrary, the point mutations of BK virus VP1 reported by Baksh et al. (43), and those identified by Smith et al. (8) in an AIDS patient, encoded for amino acid substitutions and potentially for changes of viral antigenic determinants.

In conclusion, our study demonstrates for the first time that JC virus can actively replicate in the kidneys of AIDS patients, as shown by means of morphological and molecular analyses. Furthermore, the JC virus strains isolated from renal tissue showed several genomic rearrangements in the TCR region, whereas the VP1 region was unchanged.

Because of the retrospective nature of this study, reliable clinicopathologic correlations are difficult to assess, and therefore relationships among JC virus replication, tubular damage, and clinical or laboratory findings cannot be easily identified. In addition, it is worth stressing that all but one case displayed normal serum creatinine levels and that the only one with increased creatinine levels did not show morphologic evidence of viral replication in renal tubules, suggesting that other factors (e.g., drugs and/or metabolic damages) could be responsible for the renal damage.

More extensive studies of a larger number of cases are needed to elucidate the precise relationships between the significance of the rearrangements and genomic mutations in JC virus DNA and the frequency of viral replication, and their possible consequences on renal function.

\section{REFERENCES}

1. Weiner LP, Herndon RM, Narayan O, Johnson RT, Shah K, Rubinstein LJ, et al. Isolation of virus related to SV40 from patient with progressive multifocal leukoencephalopathy. N Engl J Med 1972;286:385-90.

2. Berger JR, Major EO. Progressive multifocal leukoencephalopathy. Semin Neurol 1999;19:193-200.

3. Manz HJ, Dinsdale HB, Morrin P. Progressive multifocal leukoencephalopathy after renal transplantation. Ann Intern Med 1971;75:77-81.

4. Bjerrum OW, Hansen OE. Progressive multifocal leucoencephalopathy in Hodgkin's disease. Scand J Haematol 1985; 34:442-5.

5. Rosenbloom MA, Uphoff DF. The association of progressive multifocal leukoencephalopathy and sarcoidosis. Chest 1983;83:572-5.

6. Major EO, Amemya K, Tornatore CS, Houff SA, Berger JR. Pathogenesis and molecular biology of progressive multifocal leukoencephalopathy, the JC virus-induced demyelinating disease of the human brain. Clin Microbiol Rev 1992;5:49-63.

7. Randhawa PS, Finkelstein S, Scantlebury V, Shapiro R, Vivas C, Jordan $\mathrm{M}$, et al. Human polyoma virus-associated interstitial nephritis in the allograft kidney. Transplantation 1999; 67:103-9.

8. Smith RD, Galla JH, Skahan K, Anderson P, Linnemann CC Jr, Ault GS, et al. Tubulointerstitial nephritis due to a mutant polyomavirus BK virus strain, BKV (Cin), causing end-stage renal disease. J Clin Microbiol 1998;36:1660-5.

9. Nebuloni M, Tosoni A, Boldorini R, Monga G, Carsana L, Bonetto S, et al. BK virus renal infection in a patient with the acquired immunodeficiency syndrome. Arch Pathol Lab Med 1999;123:807-11.

10. Boldorini R, Omodeo-Zorini E, Suno A, Benigni E, Nebuloni $\mathrm{M}$, Garino E, et al. Molecular characterization and sequence analysis of polyomavirus strains isolated from needle biopsy specimens of kidney allograft recipients. Am J Clin Pathol 2001;116:489-94.

11. Randhawa P, Baksh F, Aoki N, Tschirhart D, Finkelstein S. JC virus infection in allograft kidneys. Transplantation 2001;71: $1300-3$.

12. Jensen PN, Major EO. A classification scheme for human polyomavirus JCV variants based on the nucleotide sequence of the noncoding regulatory region. J Neurovirol 2001;7:280-7.

13. Shinohara T, Matsuda M, Cheng SH, Marshall J, Fujita M, Nagashima K. BK virus infection of the human urinary tract. J Med Virol 1993;41:301-5.

14. Hsu SM, Raine L, Fanger H. Use of avidin-biotin-peroxidase complex $(\mathrm{ABC})$ in immunoperoxidase techniques: a comparison between $\mathrm{ABC}$ and unlabeled antibody (PAP) procedures. J Histochem Cytochem 1981;29:577-80.

15. Ferrante P, Caldarelli-Stefano R, Omodeo-Zorini E, Vago L, Boldorini R, Costanzi G. PCR detection of JC virus DNA in brain tissue from patients with and without of progressive multifocal leukoencephalopathy. J Med Virol 1995;47:219-25.

16. Arthur RR, Dagostin S, Shah KV. Detection of BK virus and JC virus in urine and brain tissue by the polymerase chain reaction. J Clin Microbiol 1989;27:1174-9.

17. Bergsagel DJ, Finegold MJ, Butel JS, Kupsky WJ, Garcea RL. DNA sequences similar to those of simian virus 40 in ependymomas and choroid plexus tumors of childhood. N Engl J Med 1992;326:988-93.

18. Flaegstad T, Sundsfjord A, Arthur RR, Pedersen M, Traavik T, Subramani S. Amplification and sequencing of the control regions of $\mathrm{BK}$ and JC virus from human urine by polymerase chain reaction. Virology 1991;180:553-60.

19. Dorries K, Vogel E, Gunther S, Czub S. Infection of human polyomaviruses JC and BK in peripheral blood leukocytes from immunocompetent individuals. Virology 1994;198:59-70.

20. Caldarelli-Stefano R, Vago L, Omodeo-Zorini E, Mediati M, Losciale L, Nebuloni M, et al. Detection and typing of JC virus in autopsy brains and extraneural organs of AIDS patients and non-immunocompromised individuals. J Neurovirol 1999;5:125-33.

21. Nickeleit V, Hirsch HH, Zeiler M, Gudat F, Prince O, Thiel G, et al. BK-virus nephropathy in renal transplants-tubular necrosis, MHC-class II expression and rejection in a puzzling game. Nephrol Dial Transplant 2000;15:324-32.

22. Ault GS, Stoner GL. Human polyomavirus JC promoter/enhancer rearrangement patterns from progressive multifocal leukoencephalopathy brain are unique derivatives of a single archetypal structure. J Gen Virol 1993;74:1499-507.

23. Yogo Y, Kitamura T, Sugimoto C, Ueki T, Aso Y, Hara K, et al. Isolation of a possible archetypal JC virus DNA sequence from nonimmunocompromised individuals. J Virol 1990;64:3139-43.

24. Vaz B, Cinque P, Pickhardt M, Weber T. Analysis of the transcriptional control region in progressive multifocal leukoencephalopathy. J Neurovirol 2000;6:398-409.

25. Gronostajski RM. Roles of the NF1/CTF gene family in transcription and development. Gene 2000;249:31-45.

26. Agostini HT, Ryschkewitsch CF, Stoner GL. Genotype profile of human polyomavirus JC excreted in urine of immunocompetent individuals. J Clin Microbiol 1996;34:159-64.

27. Nickeleit V, Hirsch HH, Binet IF, Gudat F, Prince O, Dalquen $\mathrm{P}$, et al. Polyomavirus infection of renal allograft recipients: 
from latent infection to manifest disease. J Am Soc Nephrol 1999;10:1080-9.

28. Shah KV. Polyomaviruses. In: Fields BN, Knipe DM, Howley P, editors. Fields virology, 3rd ed. Philadelphia: LippincottRaven; 1996. p. 2027-43.

29. Gardner SD, MacKenzie EF, Smith C, Porter AA. Prospective study of the human polyomaviruses $\mathrm{BK}$ and JC and cytomegalovirus in renal transplant recipients. J Clin Pathol 1984;37:578-86.

30. Chesters PM, Heritage J, McCance DJ. Persistence of DNA sequences of BK virus and JC virus in normal human tissues and in diseased tissues. J Infect Dis 1983;147:676-84.

31. Tominaga T, Yogo Y, Kitamura T, Aso Y. Persistence of archetypal JC virus DNA in normal renal tissue derived from tumor-bearing patients. Virology 1992;186:736-41.

32. Aoki N, Kitamura T, Tominaga T, Fukumori N, Sakamoto Y, Kato K, et al. Immunohistochemical detection of JC virus in nontumorous renal tissue of a patient with renal cancer but without progressive multifocal leukoencephalopathy. J Clin Microbiol 1999;37:1165-7.

33. Dorries K, ter Meulen V. Progressive multifocal leukoencephalopathy: detection of papovavirus JC in kidney tissue. J Med Virol 1983;11:307-17.

34. Boldorini R, Zorini EO, Fortunato M, Bernardi M, Suno A, Benigni E, et al. Molecular characterization and sequence analysis of polyomavirus BKV-strain in a renal-allograft recipient. Hum Pathol 2001;32:656-9.

35. Agostini HT, Ryschkewitsch CF, Stoner GL. Rearrangements of archetypal regulatory regions in JC virus genomes from urine. Res Virol 1998;149:163-70.
36. Weggen S, Bayer TA, von Deimling A, Reifenberger G, von Schweinitz D, Wiestler OD, et al. Low frequency of SV40, JC and BK polyomavirus sequences in human medulloblastomas, meningiomas and ependymomas. Brain Pathol 2000;10:85-92.

37. Elsner C, Dorries K. Human polyomavirus JC control region variants in persistently infected CNS and kidney tissue. J Gen Virol 1998;79:789-99.

38. Iida T, Kitamura T, Guo J, Taguchi F, Aso Y, Nagashima K, et al. Origin of JC polyomavirus variants associated with progressive multifocal leukoencephalopathy. Proc Natl Acad Sci USA 1993;90:5060-5.

39. Newman JT, Frisque RJ. Identification of JC virus variants in multiple tissue of pediatric and adult PML patients. J Med Virol 1999;58:79-86.

40. Martin JD, King DM, Slauch JM, Frisque RJ. Differences in regulatory sequences of naturally occurring JC virus variants. J Virol 1985;53:306-11.

41. Pfister LA, Letvin N, Koralnik IJ. JC virus regulatory region tandem repeats in plasma and central nervous system isolates correlate with poor clinical outcome in patients with progressive multifocal leukoencephalopathy. J Virol 2001;75:5672-6.

42. Daniel AM, Swenson JJ, Mayreddy RP, Khalili K, Frisque RJ. Sequences within the early and late promoters of archetype JC virus restrict viral DNA replication and infectivity. Virology 1996;216:90-101.

43. Baksh FK, Finkelstein SD, Swalsky PA, Stoner GL, Ryschkewitsch CF, Randhawa P. Molecular genotyping of BK and JC viruses in human polyomavirus-associated interstitial nephritis after renal transplantation. Am J Kidney Dis 2001;38:354-65.

\section{Book Review}

\section{Newman WR, Principe LM: Alchemy Tried in Fire: Starkey, Boyle, and the Fate of Hel- montian Chymistry, 296 pp, Chicago, Uni- versity of Chicago Press, 2002 (\$40.00).}

Robert Boyle (1627-1691), the English philosopher, physicist, and chemist, is best known for Boyle's law, describing the pressure-volume relationship of gases at constant temperature. In 1661 he wrote The Skeptical Chemist a catchy title that has since been borrowed and modified many a time for 'the skeptical this' and 'the skeptical that.' Indeed, the present item might easily have been called the "The Skeptical Alchemist," who turns out to be a man called George Starkey (1628-1665), whom you will have more difficulty locating in the timetables of history. The third subject is Johann Baptista van Helmont (1577-1644), Flemish physician and scientist.

Nobody could doubt Boyle's commitment to quantitation. The thrust of Alchemy Tried in Fire seems to be that Starkey and van Helmont also had a good feel for measurement and that the influences of the pair on Boyle have been underrated. Unfortunately, one cannot forget van Helmont's famous willow experiment in which he claimed that the only thing a growing tree got from the soil was water, and the world had to wait for the English botanist and chemist Stephen Hales (16711761) to get it right.

Perhaps a short quote (page 316) will best represent the authors. 'In the present book we have re-joined some of the dissevered parts of the broad chymical [sic] tradition and argued for early modern chemistry's vitality and independence as a discipline. Our contention that rational laboratory practice and methodology provide a locus of continuity between 'alchemy' and 'chemistry' rather than acting as a new, defining characteristic of the latter may surprise some readers.' The authors repeatedly use "chemical' and 'chymical' as if defining their subjects but never explain their choice; the index does not help. They have a penchant for quoting 'olde' English and letting the reader labor through it under the pretense that modernization would lose the content. Newman and Principe seem to be writing for each other and show no great interest in expanding their subject for a general audience.

\section{Wilfred Niels Arnold \\ University of Kansas Medical Center \\ Kansas City, Kansas}

